\title{
Factors Affecting Late Infertility Examination
}

\author{
Uki Retno Budihastuti ${ }^{1,2)}$, Eriana Melinawati1,2), \\ Arum Dessy Rahma Sari'), Abida Zuhra Jatiningtyas's)
}

\author{
${ }^{1)}$ Department of Obstetrics and Gynecology, Dr. Moewardi Hospital, Surakarta \\ ${ }^{2)}$ Faculty of Medicine, Universitas Sebelas Maret
}

\section{ABSTRACT}

Background: Infertility is the inability of a couple to get pregnant after 12 months of regular sexual intercourse at least 2-3 times a week without using contraception. Delay in the examination will have a bad impact considering that increasing age will affect the success of the handling of infertility, especially in women so it is necessary to know the factors that influence the delay of the initial examination in order to be overcome. This study aims to determine the factors that influence the late infertility examination.

Subjects and Method: This was an analytic observational study with a cross sectional design. The study was conducted at Sekar Polyclinic, Dr. Moewardi Hospital, Surakarta, Central Java, from June to August 2019. A sample of 90 outpatients was selected by purposive sampling. The dependent variable was late infertility examination. The independent variables were family support, knowledge, accessibility, and education. The data was collected by medical record and questionnaire. The data were analyzed by a multiple logistic regression.

Results: Late infertility examination decreased with strong family support $(\mathrm{OR}=0.20 ; 95 \% \mathrm{CI}=$ 0.06 to $0.62 ; \mathrm{p}=0.006)$, high knowledge $(\mathrm{OR}=$ $0.29 ; 95 \% \mathrm{CI}=0.09$ to $0.92 ; \mathrm{p}=0.036)$, $\operatorname{good}$ accessibility $(\mathrm{OR}=0.18 ; 95 \% \mathrm{CI}=0.05$ to $0.59 ; \mathrm{p}=$ $0.005)$, and high education $(\mathrm{OR}=3.41 ; 95 \% \mathrm{CI}=$ 0.95 to $12.17 ; \mathrm{p}=0.059$ ).

Conclusion: Late infertility examination decreases with strong family support, high knowledge, good accessibility, and high education.

Keywords: infertility examination, family support, accessibility, knowledge

\section{Correspondence:}

Uki Retno Budihastuti. Department of Obstetrics and Gynecology, Dr. Moewardi Hospital,Jl. Kolonel Sutarto132, Jebres, Surakarta, Central Java. Email: ukiretno@gmail.com. Mobile: 08122656140.

Cite this as:

Budihastuti UR, Melinawati E, Sari ADR, Jatiningtyas AZ (2020). Factors Affecting Late Infertility Examination. J Matern Child Health. 5(2): 206-212. https://doi.org/10.26911/thejmch.2020.05.02.11

(c) (i) (-) Journal of Maternal and Child Health is licensed under a Creative Commons Attribution-Non Commercial-Share Alike 4.o International License.

\section{BACKGROUND}

Living things in preserving their offspring require the process of breeding. It is common knowledge that almost every married couple wants the presence of a child to supplement their family. However, this is difficult to realize for patients with infertile conditions. Infertility can be interpreted as the inability of a partner to get pregnant after 12 months of regular sexual intercourse at least 2-3 times a week on a regular basis without using contraception (Zegers-Hochschild et al., 2009).
This condition can be caused by various factors such as husband, wife, and other causes. This infertility problem can adversely affect married couples. Besides causing medical problems, infertility can have a negative psychological and economic impact (Hiferi et al., 2013). This is caused by high hopes to have children personally, interpersonal, social, and religious. If this condition is allowed to drag on it will cause depression and other pathological conditions and will certainly incur more costs for treatment (Fido and Zahid, 2004). 
A household health survey in Indonesia in 1996 showed that there were an estimated 3.5 million couples ( 7 million people) who were infertile. Whereas at present, the incidence of infertility is increasing by $15^{-}$ $20 \%$ from around 50 million couples in Indonesia (Hiferi et al., 2013). Only a few couples among the many infertility patients who do timely checks that is after one year of marriage have not experienced pregnancy.

Delay in the examination will certainly have a negative impact given that increasing age will affect the success of handling infertility, especially in women. Egg reserves are reduced by increasing age to be an adverse factor in the management of infertility. The egg cell that a woman has at birth in the world is 700,000-1,000,000. This amount will gradually decrease along with $300-400$ times ovulation so that it eventually wears off during menopause (Alviggi et al., 2009). In addition, infertile cases will be increasingly difficult to handle, especially those caused by infection. This certainly will lead to psychological and economic problems of the patient.

Patient's delay in checking their infertility complaints is due to several factors. Socio-economic problems, lack of moral support, lack of understanding, and lack of accessibility are factors that cause delays. Based on the background that has been described by the author, to overcome the delay of infertile patients conducting an examination requires knowledge of the causes. So that it is expected to be able to make patients aware of their infertility problems immediately and get timely and efficient infertility treatment.

\section{SUBJECTS AND METHOD}

\section{Study Design}

This was an analytic observational study with a cross sectional design. The study was conducted at Dr. Moewardi Hospital, Surakarta, Central Java, from July to August 2019.

\section{Population and Sample}

The study population was infertile female. A sample of 90 women who performed examinations at the Sekar polyclinic, Dr. Moewardi Hospital, Surakarta was selected for this study.

\section{Study Variables}

The dependent variable was late infertility examination. The independent variables were family support, knowledge, accessibility, and education.

\section{Operational Definition of Variables The time of infertility examination was} time interval between marriage and first time consultation of infertility. The data were collected by medical record and questionnaire. The measurement scale was continuous, and for data analysis it was transformed into dichotomous, coded $\mathrm{o}=$ not late $(1-3$ years after infertility) and $1=$ late ( $>3$ years after infertility).

Family support was the support provided by the spouse, family, or close friend, comprising financial, instrumental, informational, and emotional supports. The data were collected by questionnaire. The measurement scale was continuous, and for data analysis it was transformed into dichotomous, coded $\mathrm{O}=$ weak (score $<21.2$ ) and $1=$ strong (score $\geq 21.2$ ).

Knowledge was study subject's knowledge about infertility. The data were collected by questionnaire. The measurement scale was continuous, and for data analysis it was transformed into dichotomous, coded $\mathrm{O}=$ low (score $<21.2$ ) and $1=$ high (score $\mathbf{2 1 . 2}$ ).

Accessibility was the ability patient to use the infertility service. The data were collected by medical record and questionnaire. The measurement scale was continuous, and for data analysis it was transformed into dichotomous, coded $\mathrm{o}=$ poor $($ score $<5.7)$ and $1=$ good (score $\geq 5 \cdot 7$ ).

Income was monthly average family income for the past six months. The data were col- 
lected by questionnaire. The measurement scale was continuous, and for data analysis it was transformed into dichotomous, coded $\mathrm{o}=$ low $(<$ minimum wage $)$ and $1=$ high $(\geq$ minimum wage).

Education was the study subject's highest attainable level of education. The data were collected by questionnaire. The measurement scale was categorical, coded $\mathrm{o}=$ low $(<$ senior high school) and $1=$ high ( $\geq$ senior high school).

\section{Data Analysis}

Univariate analysis was intended to describe the characteristics of each variable. Bivariate analysis was performed to determine the relationship between the delay of initial examination with the independent variable using the Chi-square test. Multivariate analysis was performed using multiple logistic regression.

\section{Research Ethics}

Research ethics includes informed consent, anonymity, and ethical approval. Ethical clearance was obtained from the Medical Research Ethics Commission of Dr. Moewardi Hospital, Surakarta, Central Java, No. 813/VI/HREC/2019.

\section{RESULTS}

\section{Sample Characteristics}

Table 1 shows the distribution of the characteristics of the study respondents consisting of age, infertile length, income level, education level, family moral support, knowledge of infertility, and accessibility in continuous data.Most of the case group and control group respondents were aged less than 37 years, namely as many as 22 people $(71 \%)$ and 54 people (91.5\%). Based on the duration of infertility, respondents who suffered more than 3 years were 29 people (93.5\%) in the case group and 41 people (69.5\%) in the control group. The last level of education, the most cases and control groups were 19 graduates of the university (61.3\%) and 51 people (86.4\%).

Table 1. Sample characteristics

\begin{tabular}{|c|c|c|c|c|c|c|c|}
\hline \multirow{2}{*}{ Characteristics } & & \multicolumn{2}{|c|}{ On time } & \multicolumn{2}{|c|}{ Late } & \multicolumn{2}{|c|}{ Total } \\
\hline & & $\mathbf{n}$ & $\%$ & $\mathbf{n}$ & $\%$ & $\mathbf{n}$ & $\%$ \\
\hline \multirow[t]{2}{*}{ Age } & $<37$ years & 22 & 71.0 & 54 & 91.5 & 76 & 84.4 \\
\hline & $\geq 37$ years & 9 & 29.0 & 5 & 8.5 & 14 & 15.6 \\
\hline \multirow[t]{2}{*}{ Long Infertile } & $<3$ years & 2 & 6.5 & 18 & 30.5 & 20 & 22.2 \\
\hline & $\geq 3$ years & 29 & 93.5 & 41 & 69.5 & 70 & 77.8 \\
\hline \multirow[t]{2}{*}{ Education } & $\geq$ Senior high school & 19 & 61.3 & 51 & 86.4 & 70 & 77.8 \\
\hline & $<$ Senior high school & 12 & 38.7 & 8 & 13.6 & 20 & 22.2 \\
\hline \multirow[t]{2}{*}{ Income } & High ( $\geq$ minimum wage) & 23 & 74.2 & 49 & 83.0 & 72 & 80.0 \\
\hline & Low (<minimum wage) & 8 & 25.8 & 10 & 17.0 & 18 & 20.0 \\
\hline \multirow[t]{2}{*}{ Family support } & Strong $(\geq 21.2)$ & 9 & 29.0 & 41 & 69.5 & 50 & 55.6 \\
\hline & Weak $(<21.2)$ & 22 & 71.0 & 18 & 30.5 & 40 & 44.4 \\
\hline \multirow[t]{2}{*}{ Knowledge } & Good ( $\geq 7.8)$ & 12 & 61.3 & 45 & 76.3 & 57 & $63 \cdot 3$ \\
\hline & Poor $(<7.8)$ & 19 & 38.7 & 14 & 23.7 & 33 & 36.7 \\
\hline \multirow[t]{2}{*}{ Accessibility } & Good ( $\geq 5.7)$ & 13 & 41.9 & 40 & 67.8 & 53 & 58.9 \\
\hline & Poor $(<5.7)$ & 18 & 58.1 & 19 & 32.2 & 37 & 41.4 \\
\hline
\end{tabular}

The basic income is divided into two based on the Surakarta minimum wage in 2018 , which is Rp. 1,802,700. The majority of samples income above regional minimum wage is 72 people (80\%). The value of family support, knowledge, and accessibility are divided into two based on the average value acquisition. Moral support, knowledge of disease, and good accessibility were mostly owned by the control group respondents, namely 41 people (69.5\%), 45 people (76.3\%), and 40 people $(67.8 \%)$. 
Table 2. Results of bivariate analysis of factors affecting the delay of initial infertility examination

\begin{tabular}{|c|c|c|c|c|c|c|c|c|}
\hline \multirow{3}{*}{ Variable } & \multicolumn{4}{|c|}{ Late infertility check } & \multirow{2}{*}{\multicolumn{2}{|c|}{ Total }} & \multirow{3}{*}{$\mathbf{O R}$} & \multirow{3}{*}{$\mathbf{p}$} \\
\hline & \multicolumn{2}{|c|}{ No } & \multicolumn{2}{|c|}{ Yes } & & & & \\
\hline & $\mathbf{N}$ & $\%$ & $\mathbf{N}$ & $\%$ & $\mathrm{~N}$ & $\%$ & & \\
\hline Family Support & & & & & & & & \\
\hline Strong & 41 & 69.5 & 22 & 29 & 63 & 98.5 & 0.18 & $<0.001$ \\
\hline Weak & 18 & 30.5 & 9 & 71 & 27 & 101.5 & & \\
\hline Knowledge & & & & & & & & \\
\hline Good & 45 & 76.3 & 12 & 61.3 & 57 & 137.6 & 0.19 & $<0.001$ \\
\hline Poor & 14 & 23.7 & 19 & 38.7 & 33 & 62.4 & & \\
\hline Accessibility & & & & & & & & \\
\hline Good & 40 & 67.8 & 13 & 41.9 & 53 & 109.7 & 0.34 & 0.018 \\
\hline Poor & 19 & 32.2 & 18 & 58.1 & 37 & 90.3 & & \\
\hline Education & & & & & & & & \\
\hline$<$ Senior highs school & 8 & 86.4 & 12 & 61.3 & 20 & $147 \cdot 7$ & 4.03 & 0.006 \\
\hline $\begin{array}{l}\geq \text { Senior highs school } \\
\text { Income }\end{array}$ & 51 & 13.6 & 19 & 38.7 & 70 & 52.3 & & \\
\hline Low & 10 & 83 & 8 & 74.2 & 18 & 157.2 & 1.70 & 0.318 \\
\hline High & 49 & 17 & 23 & 25.8 & 72 & 42.8 & & \\
\hline
\end{tabular}

\section{The result of bivariate analysis}

Table 2 shows the results of the bivariate analysis. The delay in the initial examination was significantly affected by family moral support $(\mathrm{OR}=0.18 ; \mathrm{p}<0.001)$, level of knowledge about infertility $(\mathrm{OR}=0.19 ; \mathrm{p}<0.001)$, accessibility $(\mathrm{OR}=0.34 ; \mathrm{p}=0.018)$, and education level $(\mathrm{OR}=4.03 ; \mathrm{p}=0.006)$. Delay in initial infertility checks is not significantly affected by the level of basic income (OR= $1.70 ; \mathrm{p}=0.318)$.

3. The result of multilevel analysis

Based on Table 3, strong family support $(\mathrm{OR}=0.20 ; \mathrm{p}=0.006)$, high knowledge $(\mathrm{OR}=$ $0.29 ; \mathrm{p}=0.036)$, good accessibility $(\mathrm{OR}=$ $0.18 ; \mathrm{p}=0.005)$, and high education $(\mathrm{OR}=$ $3.41 ; \mathrm{p}=0.059)$ reduced the likelihood of late infertility examination.

Table 3. The results of multiple logistic regression on the relationships of family support, knowledge, accessibility, and education on late infertility examination

\begin{tabular}{lcccc}
\hline \multicolumn{1}{c}{ Independent Variable } & \multirow{2}{*}{ OR } & \multicolumn{2}{c}{$\mathbf{9 5 \%}$ CI } & \multirow{2}{*}{ p } \\
\cline { 3 - 4 } & & Lower Limit & Upper Limit & \\
\hline Family Support (strong) & 0.20 & 0.06 & 0.62 & 0.006 \\
Knowledge (high) & 0.29 & 0.09 & 0.92 & 0.036 \\
Accessibility (good) & 0.18 & 0.05 & 0.59 & 0.005 \\
Education ( $\geq$ senior high school) & 3.41 & 0.95 & 12.17 & 0.059 \\
n observation=90 & & & & \\
Log likelihood = -866.94 & & & \\
Adj R Square = 0.72 & & & \\
p = 0.001 & & & \\
\hline
\end{tabular}

\section{DISCUSSION}

1. Relationship of family support on late infertility examination

Based on the results of the study, family social support influences the delay in the initial examination of infertility. The better the support provided, the lower the risk of delay in checking. Mariana et al. (2011), states that family support can provide a protective effect on infertile women who experience stress. In 85 women who examined themselves for infertility, it was found that 
the role of interpersonal especially family support is one of the factors that encourage women to check themselves and participate in infertility therapy programs.

The social stigma of childless couples leads to isolation and neglect in many developing countries so that family support can also be a coping mechanism for couples experiencing infertility to fight the stigma (Mahajan et al., 2009; Martins, et al., 2014).Strong family support can provide confidence to couples who experience delays in pregnancy to check themselves. It also can be coping mechanism on couples who experience stress. Strong family support decreases the risk of late infertility examination.

\section{Relationship of knowledge on late infertility examination}

Based on the results of this study, knowledge influences the delay in the initial examination of infertility. The better knowledge about infertility will reduce the risk of late examination.

Kopper and Smith (2001) stated that, respondents do not have a strong attitude regarding infertility and infertility treatment due to lack of experience and exposure to the problem. Specific definitions of infertility are not given to respondents so couples who do not have children will act according to their understanding rather than in terms of medical infertility. From 31 study articles regarding reproductive care needs, it can be concluded that information needs regarding reproduction are important, one of the reproductive information needs needed is knowledge of infertility (Hasanbeygi et al., 2017).

High knowledge decreases the risk of late infertility examination. Individuals with high knowledge of infertility are more aware than individuals with poor knowledge. If there are symptoms that lead to the disease so that it will encourage them to immediately find out through medical examination.

\section{Relationship of accessibility on late infertility examination}

Access affects delay of the initial infertility consultation. Close distance and affordability of service increase timeliness of initial infertility consultation. It was reported that one of the obstacles in conducting infertility screening and treatment is the distance that individuals need to travel to reach health facilities that provide infertility care. Not only in the initial examination, but also in treatment requires repeated visits and the ability to follow complicated therapeutic instructions (Wu et al., 2013).

Accessibility of health service is an important component to the ease of the fertility examination can be reached by an individual. Good accessibility decreases the risk of late infertility examination

\section{Relationship of education level to late infertility screening}

Based on the results of this study, the level of education influences the delay in the initial examination of infertility. The lower level of education will increase the risk of delay in examinations.

This finding was supported by Schiller et al. (2012), which stated that there are differences in educational attainment with self-health assessment. Individuals with higher education level will tend to be able to assess their health better than individuals who have lower education status.

Eisenberg et al. (2010) stated that women with less education from tertiary institutions would risk not taking care of infertility compared to women with tertiary education. The low level of education will have an impact on the level of acceptance and understanding of knowledge of the disease to be less, so that it will cause respondents to not know about the examination of early detection (Romadani, 2014). High level of education can improve individuals knowled 
ge. Individuals who have a higher level of education will have a better awareness of their health so that they will be more alert in looking for their health needs. In conclusion, patient's delay in checking their infertility complaints is due to several factors. Strong family support, high knowledge, good accessibility, and high education decreases the risk of late infertility examination.

\section{AUTHOR CONTRIBUTION}

Uki Retno Budhiatuti and Eriana Melinawati formulated the conceptual framework and wrote research methodology. Arum Dessy and Abida Zuhra Jatiningtyas collected and analyzed data.

\section{CONFLICT OF INTEREST}

There is no conflict of interest in this study.

\section{FUNDING AND SPONSORSHIP}

This study used fund from Dr. Moewardi Hospital Surakarta Education and Research Section.

\section{ACKNOWLEDGEMENT}

We thank Dr. Moewardi Hospital for their permission and cooperation to conduct research at this hospital.

\section{REFERENCE}

Alviggi C, Humaidan P, Howles CM, Tredway D, Hillier SG (2009). Biological versus chronological ovarian age: Implications for assisted reproductive technology. Reprod Biol Endocrinol, 7:101. https://doi.org/10.1186/1477-7827-7-101

Committee E, Society A (2015). Disparities in access to effective treatment for infertility in the United States: An ethics committee opinion. Fertil Steril, 104(5):1104-1110. https://doi.org/10.1016/j.fertnstert.2015.07.1139

Eisenberg ML, Smith JF, Millstein SG, Nachtigall RD, Adler NE, Pasch LA,
Katz PP (2010). Predictors of not pursuing infertility treatment after an infertility diagnosis: Examination of a prospective US. Fertil Steril, 94(6): 2369-2371. https://doi.org/10.1016/j.fertnstert.2010.03.068

Fido A, Zahid MA (2004). Coping with infertility among Kuwaiti women: Cultural perspectives. Int J of Soc Psychiatry, 50(4): 294-300. https://doi.org/10.1177/0020764004050334

Hasanbeygi F, Zandi M, Vanaki Z, Kazemnejad A (2017). Investigating the problems and needs of infertile patients referring to assisted reproduction centers: A review study. Evidence Based Care Journal, 7(3): 54-70. https://doi.org/10.22038/ebcj.2017.26250.1608

Hiferi, Perfitri, Iaui, Pogi (2013). Konsensus Penanganan Infertilitas (Consensus on Infertility Management). Konsensus Penanganan Infertil.

Kopper BA, Smith MS (2001). Knowledge and attitudes toward infertility and childless couples. J ApplSoc Psychol, 31(11): 2275-2291. https://doi.org/10.1111/j.1559-1816.2001.tboo175.x

Mahajan NN, Turnbull DA, Davies MJ, Jindal UN, Briggs NE, Taplin JE (2009). Adjustment to infertility: The role of intrapersonal and interpersonal resources/vulnerabilities. Hum Reprod, 24(4): 906-912. https://doi.org/10.1093/humrep/den462.

Martins MV, Peterson BD, Almeida VM, Costa ME (2011). Direct and indirect effects of perceived social support on womens infertility-related stress. Hum Reprod, 26(8): 2113-2121. https://doi.org/10.1093/humrep/der157.

Martins MV, Peterson BD, Almeida V, Mesquita-Guimarães J, CostaME (2014). Dyadic dynamics of perceived social support in couples facing infertility. Hum Reprod, 29(1): 83-89. https://- 
doi.org/10.1093/humrep/det403.

Romadani DI (2014). Description of cervical cancer patients who are late in the early detection of cervical cancer. Retrieved from http://eprints.ums.ac.id/30734/. Schiller JS, Lucas JW, Peregoy JA (2012). Summary health statistics for US adults: National Health Interview Survey, 2011. VitalHealth Stat Series, 10(256): 1-80. Retrieved from https://www.ncbi.nlm.nih.gov/pubmed/25116400

Wu AK, Elliott P, Katz PP, Smith JF (2013). Time costs of fertility care: The hidden hardship of building a family. Fertility and Sterility, 99(7): 2025-2030. https://doi.org/10.1016/j.fertnstert.2013.01.145

Zegers-Hochschild F, Adamson GD, de Mouzon J, Ishihara O, Mansour R, Nygren $\mathrm{K}$ et al. (2009). International committee for monitoring assisted reproductive technology (ICMART) and the world health organization (WHO) revised glossary of ART terminology, 2009. Fertil and Steril, 92(5): 1520-1524. https://doi.org/10.1016/j.fertns-tert.2009.09.009 